\title{
THE EMERGENCE AND GROWTH OF THE ON-LINE SERIOUS GAMES AND PARTICIPATORY SIMULATION GROUP "APLSO"
}

\author{
Zofia K. Rybkowski', Thaís da C. L. Alves², and Min Liu ${ }^{3}$
}

\begin{abstract}
Lean simulations provide a critical "aha moment" that helps with the understanding and buy-in of key lean principles. The purpose of this article is to share the process of development and implementation of an ongoing international on-line Lean-IPD simulation experimentation community called Administering and Playing Lean Simulations Online (APLSO). The group emerged following the arrival of the COVID19 pandemic to include academics from 38 universities (70\%) and consultant practitioners $(30 \%)$. This paper documents the inception and growth of this community so that lessons learned can be shared with the international lean construction community. Serious games and simulations were transitioned to an online format, relying heavily on commonly available software such as Zoom ${ }^{\mathrm{TM}}$ and Google Slides ${ }^{\mathrm{TM}}$. The most frequently developed simulations tended to be those most typically played by academics and consultants prior to the pandemic. The authors classified games presented, as well as identified physical simulations still needing to be converted to an online format.
\end{abstract}

\section{KEYWORDS}

Serious games, participatory simulations, on-line simulations, COVID-19, lean principles.

\section{INTRODUCTION}

The purpose of this paper is to share the process of forming and managing a global collaborative effort to transform in-person lean construction simulations to an on-line format following the emergence of the global pandemic COVID-19.

Serious games and simulations play an important role in lean construction's growing popularity and global dissemination to the construction industry. They offer the type of controlled laboratory conditions that are usually found in the physical and biological sciences where the impact of a single variable is tested and measured between rounds of

1 Associate Professor, Department of Construction Science, Texas A\&M University, College Station, TX, 77843 USA, o: (979) 845-4354, zrybkowski@tamu.edu, orcid.org/0000-0002-0683-5004

2 Associate Professor, J. R. Filanc Construction Eng. and Mgmt. Program, Dept. of Civil, Constr., and Env. Eng., San Diego State University, San Diego, CA, USA, talves@ mail.sdsu.edu, orcid.org/00000001-7928-9190

3 Associate Professor, Department of Civil, Construction, and Environmental Engineering, North Carolina State University, Raleigh, NC USA 27695-7908, o: (919) 513-7920; E-mail: min_liu@ncsu.edu, orcid.org/0000-0002-3070-7109 
play (Rybkowski et al. 2012; Verma 2003). Because of their abilty to test and validate process decisions at low risk, simulations impart confidence to those who teach lean.

Kristin Hill, Director of Education Programs at LCI (the US-headquartered Lean Construction Institute), estimated that approximately 100 US-based construction companies impart lean principles to their employees and trade partners through serious games and simulations (personal communication, February 5, 2021). This need to test and make explicit lean principles and tools that are sometimes difficult to grasp (Liker 2004; Tzortzopoulos et al. 2020) has generated a proliferation of activity toward the development and testing of novel lean participatory simulations both from research universities (Bhatt et al. 2016; Gonzalez et al. 2014; Howell and Liu 2012; Pollesch et al. 2017; Rybkowski et al. 2011; Rybkowski and Kahler 2014; Rybkowski et al. 2016; Sacks et al. 2007), and from industry alike (Villego 2017). Most simulations for lean construction are played in person. One of the earliest known participatory lean construction simulations played digitally was the Parade-of-Trades, developed by Choo and Tommelein (1999). Although there have been pockets of experimentation to play collaborative lean construction simulations aided by computers, these arguably did not gain much traction prior to 2020 .

\section{COVID-19 AND THE EMERGENCE OF APLSO}

On March 11, 2020, the director-general of the World Health Organization declared the spread of COVID-19 to be a global pandemic. By the time of the announcement, the emerging virus had been transmitted to over 110 countries and territories. Within little more than ten days, many universities and businesses across the globe chose to transition their course work to an exclusively on-line or hybrid format, facilitated in large part by the ready availability and simplicity of the cloud-based collaborative software Zoom ${ }^{\mathrm{TM}}$. Faced with the new reality of digital or hybrid instruction, a lean consultant based in Germany e-mailed 22 internationally-based lean educators and consultants, appealing for ways to teach lean simulations on-line to help on-board new members who needed to be initiated to the Last Planner® System of Production Control (Annett Schöttle, personal communication, March 21, 2020). Finding themselves in a similarly challenging situation, the authors of this article took up the charge to organize a weekly, global, on-line lean simulation testing group which they coined as "APLSO" (Administering and Playing Lean Simulations On-Line). The original members to whom the email appeal was written were invited by the prime organizer at Texas A\&M University to meet weekly on Mondays from 12:00-1:30 pm Central Time (UTC-6), with the time established according to a cloud-based scheduling poll. Hosted at Texas A\&M University, the first meeting with 14 attendees was held via Zoom on March 30, 2020, and involved collaboratively playing the Maroon-White Game (Smith and Rybkowski 2013). The purpose of setting this specific time slot was to accommodate as many global time zones as possible, including those situated at completely opposite extremes, such as those from India and New Zealand.

\section{THE GROWTH OF APLSO}

Early attempts to convert in-person simulations to an online format were clunky and awkward: internet connections intermittently failed, and some participants complained of being forced to surrender their email addresses to software providers in order to participate. From the beginning the group used breakout rooms on Zoom, and shared files via Google Drive. However, by the time of the tenth week of play, the group experienced 
a breakthrough by transitioning to actively moving pre-defined pieces in Google Slides ${ }^{\mathrm{TM}}$ in small collaborative groups of players by using Zoom's breakout room functionsending each group a shared link set to the "editable" function. Participants were invited to facilitate their own innovative simulations with other participants in exchange for plusdelta feedback from the group during the last 15 minutes of each 90 session.

APLSO's intent was driven to fill a singular need - that is, to quickly provide a safe space dedicated to testing out newly developed interactive participatory simulations online so that lean educators could continue to offer the same caliber of instruction during social distancing that existed prior to the pandemic. A few rules were created and discussed by the group and agreed by vote, namely: (a) presentations were required to be collaboratively interactive (no straight "lectures" were permitted), (b) no recording was allowed in order to afford a sense of psychological safety to facilitators and players, and (c) simulation facilitators were asked to avoid using software that would require participants to give their email addresses to companies. Because not all players had direct access to Zoom accounts (i.e. although all could access Zoom as players, this was not always true for facilitators) the primary organizer began meeting with a presentation team the week before a new presentation, which helped facilitations run more smoothly.

\section{OUTCOMES}

The organizers were mindful and sensitive to the needs of different time zones and anticipated the possibilities for confusion when some but not all countries embraced daylight savings time. The number of registered participants grew by word-of-mouth, and when interested stakeholders sent an invitation request to the prime organizer at Texas A\&M University.

Table 1: APLSO Facilitators, their Affiliations, and their Presentations listed by Date

\begin{tabular}{|c|c|c|c|}
\hline Date & Facilitator & Affiliation & Simulation \\
\hline 03/30/20 & Zofia Rybkowski & Texas A\&M Univ., TX USA & Maroon-White Game \\
\hline 04/06/20 & Thais Alves & San Diego State Univ., CA USA & $\begin{array}{c}\text { Architectural Programming } \\
\text { Simulation }\end{array}$ \\
\hline $04 / 13 / 20$ & Colin Milberg & ASKM Associates, MA USA & $\begin{array}{c}\text { Parade of Trades (using } \\
\text { Mural) }\end{array}$ \\
\hline $04 / 20 / 20$ & Alan Mossman & The Change Business Ltd., UK & Repair Co Exercise \\
\hline $04 / 27 / 20$ & Paul Ebbs & WSP, QATAR & Introduction to 8 flows \\
\hline $05 / 04 / 20$ & Zofia Rybkowski & Texas A\&M Univ., TX USA & Choosing By Advantages \\
\hline $05 / 11 / 20$ & Paul Ebbs & WSP, QATAR & $\begin{array}{l}8 \text { flows virtual simulation } \\
\text { (cont'd) }\end{array}$ \\
\hline $05 / 18 / 20$ & Alan Mossman & The Change Business Ltd., UK & List of gaming needs \\
\hline \multirow{3}{*}{$05 / 25 / 20$} & \multirow{2}{*}{ Colin Milberg } & \multirow{2}{*}{ ASKM Associates, MA USA } & $\begin{array}{l}\text { Batch-Balance-Pull (using } \\
\text { Mural Software); }\end{array}$ \\
\hline & & & $\begin{array}{l}\text { Sim. to Lego Airplane } \\
\text { simulation }\end{array}$ \\
\hline & Annett Schöttle & Refine, GERMANY & \\
\hline $06 / 01 / 20$ & Ehsan Asnaashari & Nottingham Trent Univ., UK & House of Cards \\
\hline $06 / 08 / 20$ & $\begin{array}{l}\text { Farook Hamzeh and } \\
\text { Salam Khalife }\end{array}$ & Univ. of Alberta, CANADA & $\begin{array}{c}\text { Value capture and value } \\
\text { management }\end{array}$ \\
\hline $06 / 15 / 20$ & Min Liu & North Carolina State Univ., NC USA & Oops Game \\
\hline $06 / 22 / 20$ & Meng Wai ("Nick") Yaw & Texas A\&M Univ., TX USA & Multi-skilling game \\
\hline
\end{tabular}


Table 2: APLSO Facilitators, their Affiliations, and their Presentations listed by Date (cont.)

\begin{tabular}{|c|c|c|c|}
\hline \multirow[t]{2}{*}{$06 / 29 / 20$} & Hrishikesh Joshi & DCEC, Baroda, INDIA & 5S Numbers Game \\
\hline & Anush Neeraj & Studio Atmosis, Utter Pradesh, INDIA & \\
\hline 07/06/20 & & IGLC28 Conference: APLSO not held & \\
\hline $07 / 13 / 20$ & Alan Mossman & The Change Business Ltd., UK & $\begin{array}{l}\text { Discussion about current } \\
\text { state of gaming }\end{array}$ \\
\hline 07/20/20 & Romano Nickerson & Boulder Associates, CO USA & DPR Block Game \\
\hline 07/27/20 & $\begin{array}{c}\text { Zofia Rybkowski } \\
\text { and Ratnaprabha Borkar }\end{array}$ & Texas A\&M Univ., TX USA & Set Based Design \\
\hline 08/03/20 & Thais Alves & San Diego State Univ., CA USA & Silent Squares \\
\hline 08/10/20 & $\begin{array}{c}\text { Iris Tommelein, with } \\
\text { Rafael Vigario Coelho, } \\
\text { Vishesh Vikram Singh, } \\
\text { Sulyn Gomez Villanueva, } \\
\text { and Karilin Yiu }\end{array}$ & Univ. of California, Berkeley, CA USA & Mistakeproofing \\
\hline $08 / 17 / 20$ & Colin Milberg & ASKM Associates, MA USA & PDCA/ Kata game \\
\hline \multirow[t]{2}{*}{$08 / 24 / 20$} & Cynthia Tsao & Navilean, MA USA & Parade of Trades \\
\hline & $\begin{array}{c}\text { Fernanda Saidelles } \\
\text { Bataglin, Dani Dietz, and } \\
\text { Fabricio Vargas }\end{array}$ & $\begin{array}{l}\text { Federal Univ. of Rio Grande do Sul } \\
\text { (UFRGS), BRAZIL }\end{array}$ & \\
\hline $08 / 31 / 20$ & $\begin{array}{c}\text { Ganesh Devkar with } \\
\text { Shaurya Bhatnagar, } \\
\text { Nimish Sharma, and } \\
\text { Georgie Jacob }\end{array}$ & CEPT Univ., Ahmedabad, INDIA & Pass the Pennies \\
\hline 09/07/20 & Paz Arroyo & DPR, CA USA & Choosing by Advantages \\
\hline $10 / 05 / 20$ & Cynthia Tsao & Navilean, MA USA & BBQ pull \\
\hline $11 / 02 / 20$ & $\begin{array}{l}\text { Daniel Hall with Ming } \\
\text { Shan "Charmaine" Ng }\end{array}$ & ETH Zurich, SWITZERLAND & TVD simulation \\
\hline $12 / 07 / 20$ & $\begin{array}{c}\text { Ganesh Devkar, with } \\
\text { Shaurya Bhatnagar, } \\
\text { Georgie Jacob, and } \\
\text { Nimish Sharma }\end{array}$ & CEPT Univ., Ahmedabad, INDIA & TVD simulation \\
\hline $01 / 04 / 21$ & Cynthia Tsao & Navilean, MA USA & Parade of Trades: Part I \\
\hline $02 / 01 / 21$ & Cynthia Tsao & Navilean, MA USA & Parade of Trades: Part II \\
\hline $03 / 01 / 21$ & Rajeswari Obulam & Texas A\&M Univ., TX USA & 5S Puzzle Game \\
\hline
\end{tabular}

*For a compilation of these simulations and related references, please refer to Rybkowski et al. (2020).

Figure 1 shows the number of participants in various countries. By March 1, 2021, the number of registered unique participants reached 115, affiliated with 17 countries (Table 2 ). As of that date, faculty and students affiliated with research institutions and universities comprised $70 \%$ of participants, while companies and lean consultancies comprised 30\% (Table 2). Those affiliated with academia, as of this writing, have come from 38 universities as shown in Table 3. Participation of unique participants per meeting has varied from a minimum of 10 to a maximum of 38 , although participation has exhibited a steady trending increase over time (Figure 2). It is important to point out that this number shows that the group had to make efforts to adapt and be flexible to play the simulations with groups of varying sizes. Also, the international character of the group requires that instructions avoid jargon that may not be common to an international community. The broad range of participants speaks to the inclusive nature of the group 
and simulations played, which cater to varying levels of sophistication in terms of understanding and application of lean concepts.

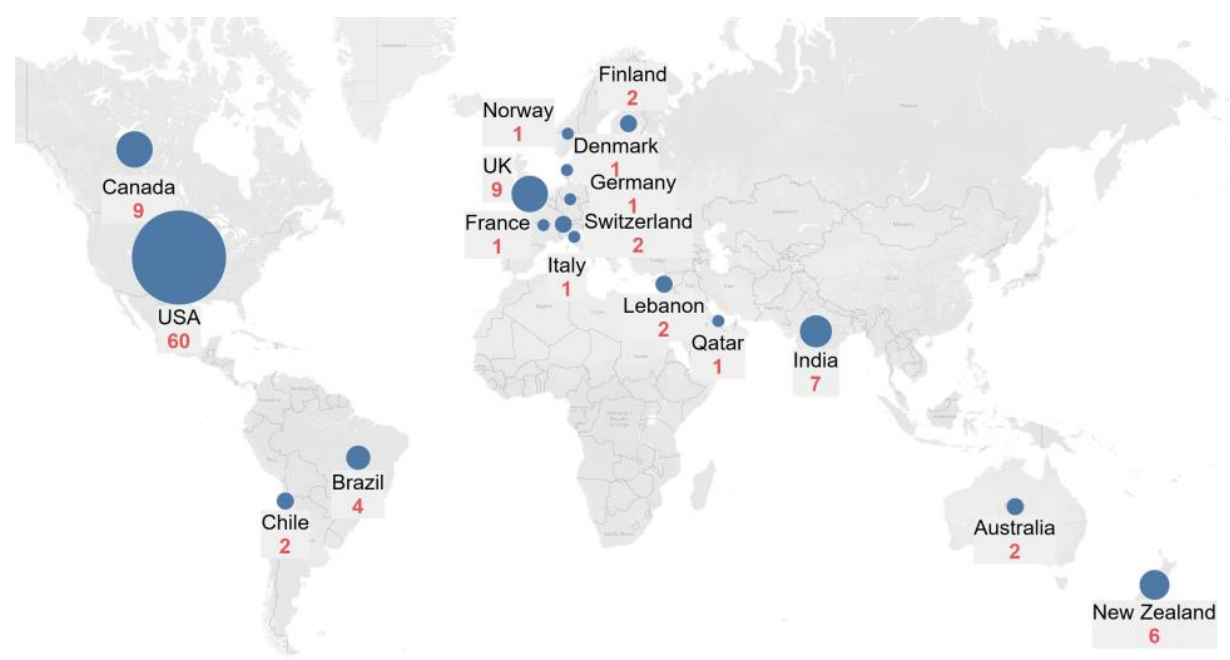

Figure 1: Location of Registered, Unique Participants

Table 3: Unique Registered Participants by Country and Type of Occupation

\begin{tabular}{|c|c|c|c|c|c|c|c|}
\hline Country & $\mathbf{R} / \mathbf{U}$ & C & Total & Country & $\mathbf{R} / \mathbf{U}$ & C & Total \\
\hline USA & 43 & 19 & 62 & Finland & 2 & & 2 \\
\hline Canada & 5 & 4 & 9 & Lebanon & 2 & & 2 \\
\hline UK & 7 & 2 & 9 & Switzerland & 2 & & 2 \\
\hline India & 6 & 3 & 9 & Denmark & & 1 & 1 \\
\hline New Zealand & 3 & 3 & 6 & France & 1 & & 1 \\
\hline Brazil & 4 & & 4 & Germany & & 1 & 1 \\
\hline Australia & 2 & & 2 & Italy & 0 & 1 & 1 \\
\hline \multirow[t]{2}{*}{ Chile } & 2 & & 2 & Norway & 1 & & 1 \\
\hline & & & & Qatar & & 1 & 1 \\
\hline $\mathrm{R} / \mathrm{U}:$ & \multicolumn{3}{|c|}{ Research Institute/ University } & & 80 & 35 & 115 \\
\hline C: & \multicolumn{3}{|c|}{ Company/ Consultancy } & & $70 \%$ & $30 \%$ & $100 \%$ \\
\hline
\end{tabular}

Several presentations - especially the most critical such as Parade of Trades and BatchBalance-Pull were played multiple times over the course of the year and continuous improvement was observed. Despite some push-back from other US-participants, the USbased APLSO organizers decided not to cancel regular Monday meetings during US (or other) non-working holidays to align with the international spirit of Lean.

Out of respect for the IGLC, the group chose not to host a regular APLSO meeting that week. Instead, as lean pioneer and simulation enthusiast Greg Howell had passed away just weeks before, the IGLC organizers invited several APLSO facilitators to present their live simulations via individual Zoom links provided by the facilitators over the course of two days (Wed, July 8, and Thurs, July 9). The rooms were named in honor of the memory Greg Howell and his seminal role as an initial developer of simulations to understand and teach lean construction. Presenters and their simulations included: Colin Milberg (Batch-Balance-Pull); Meng Wai "Nick" Yaw (Card Race); Romano Nickerson (DPR Block); Iris Tommelein and Karilin Yiu (Mistakeproofing); Cynthia Tsao (Parade of Trades); Zofia Rybkowski (Repair Co); and Hrishikesh Joshi and Anush Neeraj (5S 
Numbers Game). The IGLC organizers collected plus-delta feedback to gauge interest in hosting simulations at future IGLC conferences. These on-line simulation sessions very likely would never have taken place at the IGLC were it not for the emergence of APLSO.

Table 4: Participation by Research Institutes and Universities

\begin{tabular}{|c|c|c|c|c|c|}
\hline Affiliation & Country & Freq. & Affiliation & Country & Freq. \\
\hline $\begin{array}{l}\text { The University of } \\
\text { Melbourne }\end{array}$ & Australia & 1 & Nottingham Trent University & UK & 1 \\
\hline $\begin{array}{c}\text { University of } \\
\text { Technology, Sydney }\end{array}$ & Australia & 1 & University College London & UK & 1 \\
\hline $\begin{array}{l}\text { Federal University of } \\
\text { Rio Grande do Sul } \\
\text { (UFRGS) }\end{array}$ & Brazil & 3 & University of Huddersfield & UK & 4 \\
\hline $\begin{array}{l}\text { Universidade } \\
\text { Paranaense }\end{array}$ & Brazil & 1 & Arizona State University & USA & 1 \\
\hline $\begin{array}{l}\text { École de Technologie } \\
\text { Supérieure }\end{array}$ & Canada & 1 & Brigham Young University & USA & 1 \\
\hline University of Alberta & Canada & 3 & $\begin{array}{c}\text { Catholic University of } \\
\text { America }\end{array}$ & USA & 1 \\
\hline University of Toronto & Canada & 1 & Colorado State University & USA & 1 \\
\hline $\begin{array}{l}\text { FEUC - Federación de } \\
\text { Estudiantes de la } \\
\text { Universidad Católica }\end{array}$ & Chile & 1 & $\begin{array}{c}\text { Florida International } \\
\text { University }\end{array}$ & USA & 1 \\
\hline $\begin{array}{l}\text { Pontificia Universidad } \\
\text { Católica de Chile }\end{array}$ & Chile & 1 & George Mason University & USA & 1 \\
\hline Aalto University & Finland & 2 & Michigan State University & USA & 2 \\
\hline $\begin{array}{c}\text { Centrale Lille, a French } \\
\text { Graduate Engineering } \\
\text { School }\end{array}$ & France & 1 & $\begin{array}{c}\text { North Carolina State } \\
\text { University }\end{array}$ & USA & 3 \\
\hline $\begin{array}{l}\text { Karlsruhe Institute of } \\
\text { Technology }\end{array}$ & Germany & 1 & Northern Arizona University & USA & 4 \\
\hline CEPT University & India & 4 & San Diego State University & USA & 1 \\
\hline $\begin{array}{c}\text { American University of } \\
\text { Beirut }\end{array}$ & Lebanon & 2 & Texas A\&M University & USA & 17 \\
\hline $\begin{array}{c}\text { Auckland University of } \\
\text { Technology }\end{array}$ & $\begin{array}{l}\text { New } \\
\text { Zealand }\end{array}$ & 1 & UC Denver & USA & 1 \\
\hline University of Auckland & $\begin{array}{l}\text { New } \\
\text { Zealand }\end{array}$ & 2 & $\begin{array}{c}\text { University of California, } \\
\text { Berkeley }\end{array}$ & USA & 6 \\
\hline $\begin{array}{l}\text { Norwegian University of } \\
\text { Science and } \\
\text { Technology }\end{array}$ & Norway & 1 & University of Kentucky & USA & 2 \\
\hline $\begin{array}{c}\text { ETH Zurich (Swiss } \\
\text { Federal Institute of } \\
\text { Technology) }\end{array}$ & Switzerland & 2 & University of Oklahoma & USA & 1 \\
\hline \multirow[t]{3}{*}{$\begin{array}{l}\text { Huddersfield University } \\
\text { / Birmingham City } \\
\text { University }\end{array}$} & UK & 1 & Virginia Tech & USA & 1 \\
\hline & & & Total \# of Universities & & 38 \\
\hline & & & Total \# of Academic & & 80 \\
\hline
\end{tabular}

This was not the first time games were offered at IGLC. For example, Zofia Rybkowski live-facilitated the Maroon-White simulation at IGLC 21 in Fortaleza, Brazil in 2013 (Smith and Rybkowski 2013). She also facilitated the Collective Kaizen and Standardization simulation in IGLC 22 Oslo, Norway, 2014 (Rybkowski and Kahler 
2014). Similarly, Alan Mossman facilitated the Magic Stick/Helium Stick simulation at the IGLC 22 as well (Discovery Village n.d.). Zofia Rybkowski and James P. Smith facilitated the Architectural Programming simulation in at IGLC 27 in Dublin, Ireland in 2019 (Solhjou Khah et al. 2019). That said, IGLC 28 was the first time lean construction simulations - and indeed the entire IGLC conference - was offered via an online format.

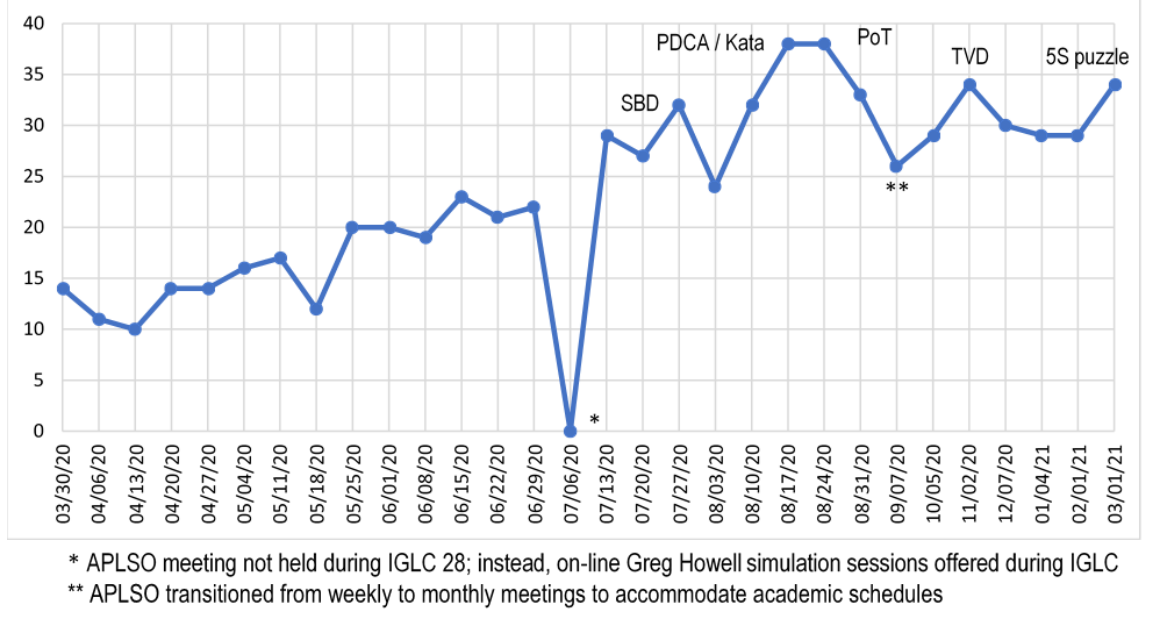

Figure 2: Longitudinal Participation by Unique Participants

Prior to 2021 the group informally shared their simulations via email and by downloading them from the Google Drive links posted in the chat section of Zoom during the APLSO sessions. Starting in 2021, participants Colin Milberg and Cynthia Tsao moved the group consciousness to a new level by making their simulations freely available through a Creative Commons Usage Agreement in exchange for plus-delta feedback and simulation data. This enabled lean educators to more openly share their on-line simulations for use during virtual university courses across the globe - one of the original purposes for creating APLSO when the pandemic emerged. A screenshot of the Parade of Trades (PoT) simulation is shown in Figure 3. It is included here to demonstrate that although the online PoT simulation may lose some of the social benefits that often come with physical play, the developers also realized that transitioning to a digital format also enabled each trade's movement to be visually tracked as it progressed up a high-rise building-something which the physical simulation lacked.

\section{DISCUSSION}

Lean tools are being applied to construction projects around the world. However, to be truly effective and to be able to grow and improve them, the underlying lean principles that inform these tools should be deeply understood by those who implement them.

In 2000, Lauri Koskela introduced the Transformation Flow Value model of lean construction. The definition of lean published in the Lean Construction Institute's glossary is: "Culture of respect and continuous improvement aimed at creating more value for the customer while identifying and eliminating waste" (LCI 2021; Rybkowski et al. 2013). The LCI definition can help classify existing on-line lean simulations into each of the four elements stated, and identify gaps where new on-line simulations have yet to be developed. Simulations in italics (below) can currently be played on-line as an outcome of efforts by APLSO, whereas those without italics represent a sampling of physical simulations that still need to be transformed into a collaborative on-line format. 


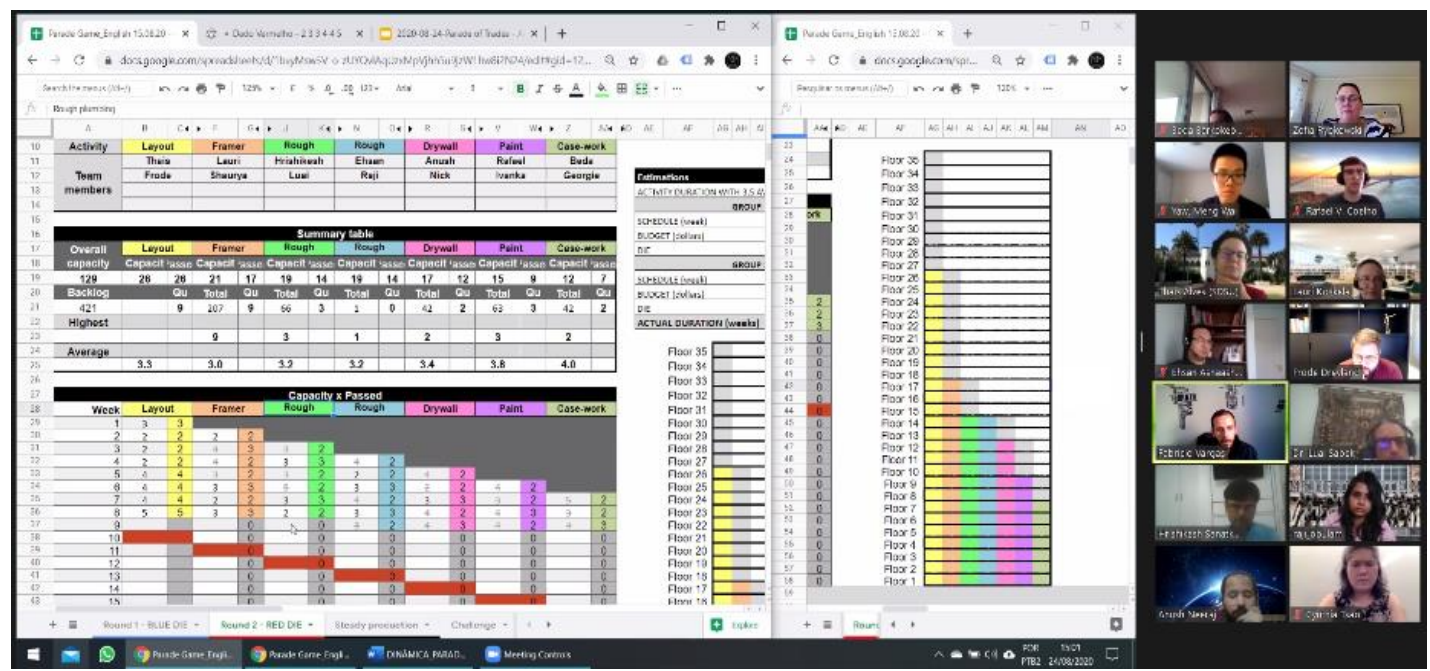

Figure 3: Example of APLSO Simulation Facilitated during APLSO (Parade of Trades, facilitated by Cynthia Tsao and Colin Milberg on August 24, 2020)

1. Add Value: Choosing by Advantages Exercise; TVD Simulation; Oops Game; AP Simulation; A3s;

2. Reduce Waste: $5 S$; Lego ${ }^{\circledR}$ Airplane Game (Batch-Balance-Pull, Pass the pennies); Parade of Trades; DPR Blocks; Mistakeproofing; BBQ Pull; Multiskilling game; Value Stream Mapping; Villego;

3. Continuous Improvement: Plus-Delta charts; House of Cards; Collective Kaizen and Standardization; Ball Game; and,

4. Culture of Respect: Repair Co Exercise; Red-Black Game (Variants: MaroonWhite / Red-Green) game; Silent Squares; Deming Red Bead Game; Helium Stick/ Magic Stick.

In addition to LCI's definitional categories, the need for new on-line simulations can be assessed based on classifications embedded into the Toyota Production Systems's "House of Lean" which includes concepts such as just-in-time, jidoka, heijunka, people and teamwork, continuous improvement, waste reduction, visual management, etc. (Liker 2004, Fig. 3-3). Further discussion of these principles is beyond the scope of this paper.

\section{CONCLUSION}

The purpose of this paper was to document and share the inception, growth, outcomes, and impacts of an international on-line simulation group called APLSO (Administering and Playing Lean Simulations Online) which emerged during the COVID-19 pandemic.

In total, 39 faculty members, 41 graduate students, and 35 individuals from companies/consultacies from 38 universities in 17 countries have thus far participated in the APLSO sessions. APLSO is unique in several ways including: the quick formation of the group in reaction to the pandemic challenges to effectively teach simulations online, the relatively large number of participants from both academia and industry, the variety of simulations played and concepts addressed, adaptation of technology available to fit the needs of the games and the participants, the global character of the particpants and the diversity of views considered, the cohesiveness of the community which quickly engaged on a regular basis, and the growth of participants who requested to join over time through word-of-mouth. 
The organizers believe that while the group undoubtedly began because of the global pandemic, it continued to attract a steady flow of international participants perhaps because of the importace the organizers placed on a key tenet of lean-e.g. respect for people. This respect was manifest in the decision to be as welcoming and inclusive as possible of participants from multiple generations, cultures, and time zones, as well as with differing levels of prior understanding of lean-students, faculty, and practitioners alike. Embracing such a diverse range of members did lead to some cross-cultural challenges, such as confusion about the flow of ingredients for an outdoor barbeque on which one simualation was based. To ensure a sense of psychological safety for developers and participants who might be sharing and testing their new simulation for the first time, APLSO participants voted to not permit recording. Several developers made their simulations freely available through a creative commons license or via email request, which helped fill the need created by the pandemic to play simulations online. APLSO also led to some unexpected outcomes, such as an invitation from the IGLC organizers to create a number of on-line game rooms for the first time during the conference, as well as an initiative from LCI to partner with several APLSO facilitators to convert on-line simulations into dedicated educational offerings. Unlike an international conference, the agenda of APLSO was simple - to regularly make available a 90-minute interactive session where lean enthusiasts could collaboratively test simulations they had developed with participants who care about lean - and in turn receive their feedback.

\section{ACKNOWLEDGMENT}

The authors gratefully acknowledge the contribution of Chuanni He of North Carolina State University for assisting the authors in his preparation of Figure 1, as well as the Texas A\&M Construction Industry Advisory Council (CIAC) for partial funding of this research.

\section{REFERENCES}

Bhatt, Y., Rybkowski, Z.K., Kalantar, N. and Fernandez-Solis, J.L. (2016). "Trainathon lean simulation game: Determining perceptions of the value of training among construction stakeholders," Proc. 24th Annual Conf. of the Int. Group for Lean Construction, Boston, MA, USA.

Choo, H.J. and Tommelein, I.D. (1999). "Parade of Trades: A Computer Game for Understanding Variability and Dependence." Technical Report 99-1, Construction Eng. and Mgmt. Program, Civil and Env. Eng. Dept., University of California, Berkeley, September. https://p2sl.berkeley.edu/knowledge-center/parade-of-tradesgame/ (Accessed June 10, 2021).

Gonzalez, V., Senior, B., Orozco, F., Alarcon, L. F., Ingle, J., and Best, A. (2014). "Simulating lean production principles in construction: A last planner-driven game," Proc. 22nd Annual Conf. of the Int. Group for Lean Construction, Oslo, Norway.

Howell, G. and Liu, M. (2012). "The Oops Game: How much planning is enough?" Proc. 20th Annual Conf. of the International Group for Lean Construction, San Diego, CA.

Koskela, L. (2000). An Exploration Towards a Production Theory and its Application to Construction. Ph.D. Dissertation, VTT Publications 408, Espoo, Finland, 296 pp.

Lean Construction Institute. (n.d.). "Glossary" Available at: https://tinyurl.com/2xnsswvb (Accessed February 14, 2021).

Liker, J. (2004). The Toyota Way: 14 Management Principles from the World's Greatest Manufacturer. McGraw-Hill, New York, USA. 
Pollesch, P., Rovinsky, A., Alvarado III, R., and Alves, T. C. L. (2017). "House of cards-A simulation of lean construction principles," Proc. 25th Annual Conf. of the Int. Group for Lean Construction, Heraklion, Greece.

Rybkowski, Z. K., Abdelhamid, T., and Forbes, L. (2013). "On the back of a cocktail napkin: An exploration of graphic definitions of lean construction,"Proceedings of the $21^{\text {th }}$ Annual Conf. for the Int. Group for Lean Construction; July 31-August 2, 2013 : Fortaleza, Brazil, 83-92.

Rybkowski, Z. K., Forbes, L. H., and Tsao, C. C. Y. (2020). "The Evolution of Lean Construction education at US-based universities." In: Lean Construction: Core Concepts and New Frontiers. Tzortzopulos, P. Kaglioglou, M., and Koskela, L. Eds. Routledge, London and New York. 387-407.

Rybkowski, Z. K. and Kahler, D. (2014). "Collective kaizen and standardization: the development and testing of a new lean simulation," Proc. 22nd Annual Conf. of the Int. Group for Lean Construction, Oslo, Norway.

Rybkowski, Z. K., Munankami, M., Gottipati, U., Lavy, S. and Fernández-Solis, J. (2011). "Impact of cost constraints on aesthetic ranking following Target Value Design exercises," Proc. 19th Annual Conf. of the Int. Group for Lean Construction, Lima, Peru.

Rybkowski, Z. K., Munankami, M., Shepley, M. M. and Fernández-Solis, J. L. (2016). "Development and testing of a lean simulation to illustrate key principles of Target Value Design: A first run study," Proc. 24th Annual Conf. of the Int. Group for Lean Construction, Boston, MA USA.

Rybkowski, Z. K., Zhou, X., Lavy, S. and Fernández-Solís, J. (2012). "Investigation into the nature of productivity gains observed during the Airplane Game lean simulation," Lean Construction Journal, 78-90.

Sacks, R., Esquenazi, A. and Goldin, M. (2007). "LEAPCON: Simulation of Lean Construction of High-Rise Apartment Buildings," Journal of Construction Engineering and Management, ASCE, 133(7), pp. 529-539.

Smith, J. P. and Rybkowski, Z. K. (2013). "The Maroon and White Game: A simulation of trust and long-term gains and losses," Proceedings of the $21^{\text {st }}$ Ann. Conf. for the Int. Group for Lean Construction; July 31-August 2, 2013: Fortaleza, Brazil, 987-996.

Solhjou Khah, F., Rybkowski, Z., Pentecost, A. R, Smith, J. P., and Muir, R. (2019). "Development and Testing of an Innovative Architectural Programming Simulation as a Precursor to Target Value Design," 27th Annual Conf. of the Int. Group for Lean Construction (IGLC), González, V.A. (ed.), July 3-5, Dublin, Ireland, pp. 515-526.

Tzortzopoulos, P., Kagioglou, M and Koskela, L., eds. (2020). Lean Construction: Core Concepts and New Frontiers. Routledge, London and New York.

Verma, A.K. (2003). "Simulation Tools and Training Programs in Lean ManufacturingCurrent Status: Final Report." National Shipbuilding Research Program, NSRP-ASE0301-11, Old Dominion Univ. Norfolk, VA.

Villego® Last Planner® Simulation (2017) Available at: ${ }^{\circledR w w . v i l l e g o . c o m / ~(A c c e s s e d: ~}$ 26th Nov 2017). 